\title{
FUTURE SCENARIOS OF TURKISH- ISRAELI RELATIONS UNDER AKP (2002-2016)
}

\author{
Rasha Mahmoud El Sayed Eid El Baz \\ Dr. Cairo University, Faculty of Economics, and Political Science, Political Science Department, \\ Egypt, rmelbaz@mcit.gov.eg
}

\begin{abstract}
The historical development of relations between Turkey and Israel, including the recent changes wrought by the AKP, show that Turkey's stance regarding Israel is driven by a mix of religious ideology and political expediency. In the early relationship between the two countries, although they experienced periods of stress, they managed to forge a strong relationship based on the mutual military and economic benefits of their relations. However, the rise of Islamist political parties in Turkey, including the NSP and the Welfare and Virtue Parties, directly harmed Turkey's relations with Israel while simultaneously strengthening Turkey's ties with Arab nations and Hamas. The current party in power, the AKP, is a continuation of Islamist parties that were previously banned, and the AKP's initial promises of reform were misleading, perhaps to reduce the chances of its being removed from power by the Turkish military, a strong defender of Turkey as a secular State. With Erdogan's 2014 presidential election victory, he has gained a chance to tighten both his and the AKP's grip on Turkish politics, an outcome that makes the future of Turkish-Israeli relations even more tenuous.
\end{abstract}

Keywords: international security, national security, pragmatism, regional security, regional power, national interest.

\section{INTRODUCTION}

Turkish-Israeli relations are unique in the Muslim world. While most Muslim-majority nations have not recognized the State of Israel, Turkey has. In fact, despite its "No" vote in the United Nations General Assembly regarding the UNSCOP Plan, Turkey was nonetheless the first Muslim-majority nation to recognize the newly established State of Israel ${ }^{1}$. There have, in fact, been periods when the two nations worked closely together and had strong ties in pursuit of common interests.

The relationship between the two countries strengthened as Turkey sought to retain strong ties with the West

\footnotetext{
${ }^{1}$ Jay Alan Sekulow, TURKEY-ISRAEL RELATIONS, Oxford Centre for the Study of Law \& Public Policy. http://policycentreatoxford.org/researchpapers/Oxford15\%20JAY\%20SEKULOW6\%20Art\%20LR\%20Format\%20TNR.pdf
} 
and emphasized the fact that Turkey was a secular, democratic republic. The relationship between Turkey and Israel has changed significantly since Turkey's Islamist political parties have gained power. This paper discusses future scenarios of relations between turkey and Israel after AKP reached power in 2002 due to the increasing Islamization of the Turkish government, which, in recent years, has pushed Turkish-Israeli relations to dramatic changes.

\section{DETERMINANTS OF TURKISH-ISRAELI RELATIONS BEFORE THE ERA OF AKP}

Before analyzing the current situation and making projections for the future, we should overview the determinants that have shaped the framework of Turkey's relationship with Israel before the era of AKP as follows:

\subsection{Historical background of Turkish-Israeli Relations}

Turkey and Israel shared many common regional interests, interests that they attempted to protect by establishing military and economic ties with one another ${ }^{2}$. Essentially, both viewed themselves as proWestern, secular, and democratic 'outsiders' in the region ..."

Arguing that Turkey's policy in the Middle East since the 1940s has been driven by its perception of geopolitical necessities, the shifts in that policy through the prism of key issues of national concern: the perception of the Soviet threat, the Cyprus issue, the water dispute with Iraq and Syria, and regionalization of the Kurdish problem. Turkey's leaders tilted toward the Arabs in the 1970s when they needed Arab diplomatic and economic support. During the 1990s, reduced trade with the Arabs, lack of Arab support on key issues, and bilateral disputes with Iraq and Syria led them to opt for closer relations with Israel ${ }^{3}$.

There was a period of improvement and growth in relations between the countries from the late 1980s into the 1990s.

Turkey and Israel enjoyed an almost perfect relationship throughout the 1990s that amazed their friends, yet bothered their rivals. The US war in Iraq revealed, however, that the two longstanding allies did indeed have contradictory objectives and concerns with respect to the future restructuring of Iraq. While Turkey fears the emergence of an independent Kurdish state in northern Iraq, the same possibility seems favorable for Israel from its security standpoint, vis-à-vis threats posed by countries like Iran, Pakistan, and beyond. It appears that the "amazing alliance" is heading toward a crossroads. Such an eventuality may change the nature of the relationship from a "win-win" to a "lose-lose" situation unless proper steps are rapidly taken with a view toward rebuilding confidence on both sides.

Turkey finally formalized its diplomatic relations with Israel when it upgraded Israel's representation to the level of ambassador in $1991^{4}$.

Israel was surprised by this development, but the upgrade followed on the heels of the 1991 Madrid Conference and reflected Turkey's desire to play a larger role in the peace talks ${ }^{5}$. Turkey's more friendly relationship with Israel during this period was largely driven by the growing role that the military played in Turkey's domestic politics. Turkey hoped to take advantage of military cooperation with Israel to further its own regional aspirations.

\subsection{Political, Economic and Military Relations}

As example the statistics released by the Israeli government document an overall volume of $\$ 5.44$ billion dollars in Turkish-Israeli trade during 2014. This marks an all-time high point in Turkish-Israeli economic relations, up 11.5 percent from 2013 , including $\$ 2.75$ billion in Israeli exports to Turkey (a 10 percent year-toyear increase) and $\$ 2.68$ billion in Turkish imports to Israel (13 percent higher than 2013).

This pattern of an almost non-existent political dialogue at the senior levels accompanied by robust bilateral trade has characterized the Turkish-Israeli relationship since 2011. Short of unexpected dramatic changes, the relations between the two former allies will likely continue in this pattern for the near future.

\footnotetext{
${ }^{2}$ Matthew S. Cohen \& Charles D. Freilich, Breakdown and Possible Restart: Turkish-Israeli Relations Under the AKP, 8 ISR. J. FOREIGN AFF. 39, 40 (2014).

${ }^{3}$ Suha Bolukbasi, Behind the Turkish-Israeli Alliance: A Turkish View, Journal of Palestine Studies, Vol. 29 No. 1, Autumn, 1999; (pp. 21-35) DOI: 10.2307/2676428 http://jps.ucpress.edu/content/29/1/21

${ }^{4}$ Arbell, supra note 20 , at 6 ; see also Kushner, supra note 20 , at 23

${ }^{5}$ Özlem Tür, Turkey and Israel in the 2000s_From Cooperation to Conflict, ISR. STUDIES, Fall 2012, at 45, 47.
} 


\subsection{Relations with Arab Countries and middle east issues (Syria, Iraq, Palestine, ...)}

In parallel with evolving economic relations between the two sides, Turkey tried to mediate between Israel and Arab and Muslim countries such as Syria and Pakistan, before relations soured following the Israeli aggression on GS in 2008. Turkey saw that event as a stab in the back, and a betrayal to its mediation efforts with Syria, in which Turkey had sponsored indirect negotiations between the two sides.

Later, bilateral relations went through several turns and crises, such as the famous incident at the World Economic Forum in Davos in September 2009, and the crisis of insulting the Turkish ambassador in Tel Aviv in January 2010. But the turning point was the Israeli assault on the Mavi Marmara ship, after which relations collapsed to their lowest point and remain so to the present day.

\subsection{Role of United states in shaping Turkish-Israeli Relations}

Enhanced standing in Washington. Cooperation between Turkey and Israel creates a synergy that increases their importance to the United States. This is especially true following the events of September 11, 2001, which starkly underlined the fact that the Israeli-Turkish entente demarcates the fringes of a region fiercely inimical to U.S. interests. Together both countries constitute a formidable force for stability that compliments U.S. interests. Perhaps its most tangible manifestation should be a lenient attitude towards defense-related technology transfers to and between the two parties, in order to ensure their undisputed military supremacy in their volatile environment.

\section{DETERMINANTS OF TURKISH-ISRAELI RELATIONS ON THE ERA OF AKP}

The Justice and Development Party's (AKP) 2002 electoral victory-building on reform that had begun under the previous coalition government, which included the Islamist Fazilet (Virtue) Party-was the beginning of a significant decline in Turkish-Israeli relations $76^{6}$. The AKP was formed in August 2001 by a group of Islamist politicians including, Recep Tayyip Erdogan, Abdullah Gül, and Bülent Arınç ${ }^{7}$. Many in the political sphere viewed the AKP as merely a continuation of the Erbakan-led Welfare Party $78^{8}$. The AKP gained a majority in the 2002 elections, forming Turkey's first majority government since the 1980 s $79^{9}$. The AKP's platform included promises to re-orient toward the West, to respect a secular Republic, and to depart from political Islam in favour of a secular, conservative democracy. At the time of the AKP's rise to power, many Turkish writers saw the issue of Turkish-Israeli relations as a benchmark for measuring the sincerity of the AKP's promise to institute a secular, Western-oriented government.

In 2003, less than five years after supposedly being banned from politics forever, Erdogan became the Prime Minister of Turkey $96^{10}$. Erdogan entered office with a foreign policy situation that allowed him to justify building close relationships with Muslim nations at the expense of Turkey's relationship with Israel. For instance, the Iraq War "and the common threat perceptions of other regional powers such as Syria and Iran, brought Turkey closer to these countries" ${ }^{\prime 1}$. A specific event that increased Turkey's reputation in the Muslim world was its rejection of the 1 March 2003 Resolution that would have allowed the United States to open a northern front in the Iraq War. Regional developments-such as the "Arab Spring" uprisings in Tunisia and Egypt-were opposed by Israel but well received by Turkey, yet another disconnect in the relationship between the two ${ }^{12}$. Even before the AKP's rise to power, Erdogan and other party leaders made public statements against Israel and in favor of the Palestinian cause, a trend that would only grow as the AKP remained in power.

When the Islamist-leaning Justice and Development Party (AKP) reached power in 2002, relations between the two countries did not deteriorate, but continue to develop with high-level mutual visits taking place. ThenTurkish Foreign Minister Abdullah Gül and then Prime Minister Recep Tayyip Erdogan both visited Israel in 2005, where they received a warm reception.

\footnotetext{
${ }^{6}$ Cohen \& Freilich, supra note 24, at 39.

${ }^{7}$ Hakan Yavuz, Adalet ve Kalkinma Partisi (AKP), OXFORD ENCYCLOPEDIA ISLAMIC WORLD, http://www.oxfordislamicstudies.com/article/opr/t236/e0924?_hi=0\&_pos=8 (last visited 10 Mar. 2015).

${ }^{8}$ Tür, supra note 56 , at 51 .

${ }^{9}$ Id.; see also Thomas Patrick Carroll, Turkey's Justice and Development Party: A Model for Democratic Islam?, MIDDLE EAST INTELLIGENCE BULLETIN, June/July 2004, http://www.meforum.org/meib/articles/0407_t1.htm.

${ }^{10}$ Turkish PM Quits for Erdogan, CNN (11 Mar. 2003), http://edition.cnn.com/2003/

WORLD/europe/03/11/turkey.elections/.

${ }^{11}$ Tür, supra note 56 , at 51

${ }^{12}$ Id. at 59-60.
} 
In parallel with evolving economic relations between the two sides, Turkey tried to mediate between Israel and Arab and Muslim countries such as Syria and Pakistan, before relations soured following the Israeli aggression on GS in 2008. Turkey saw that event as a stab in the back, and a betrayal to its mediation efforts with Syria, in which Turkey had sponsored indirect negotiations between the two sides. Later, bilateral relations went through several turns and crises, such as the famous incident at the World Economic Forum in Davos in September 2009, and the crisis of insulting the Turkish ambassador in Tel Aviv in January 2010. But the turning point was the Israeli assault on the Mavi Marmara ship, after which relations collapsed to their lowest point and remain so to the present day.

In this regard, we can set determinants that have shaped the framework of Turkey's relationship with Israel on the era of AKP as follows:

First: Building on the longstanding relationship between the two parties, and the inability to (and perhaps the absence of intent to) bring about radical and direct changes.

While relations will not return to the "love affair" of the 1990s, there is reason for cautious optimism. Rapprochement will serve to create the foundation for a stronger dialogue between two of the Middle East's most important actors ${ }^{13}$.

Second: Taking into account the political situation in the country when the AKP took power, especially the dominance of the Turkish military over the political scene, with the army maintaining special relations with Israel.

Third: The status of the relationship is a part of Turkish national security and interests, which the ruling party re-interpreted and reformulated without turning against them dramatically.

Fourth: The party's theory of the need to adapt politics to the needs of the economy including in foreign policy, in conditions of normal relations with other countries, and the separation (disengagement) between them in periods of tension, i.e., maintaining trade and economic relations in spite of political differences, which is what Turkey did even after the Mavi Marmara crisis.

Fifth: Turkey avoided direct and sharp confrontations with any party, given the difficulty of unilateral action in the absence of regional partners, regardless of how high the ceiling of its discourse has been.

Sixth: Considering the relationship with Israel part of Turkey's relations with the West-the United States of America, the European Union and NATO-and a key to gain the confidence of these parties through good relationship, or at least non-confrontation with Israel.

Seventh: Turkey's need for Israel in several areas, particularly in security cooperation and the development of weapons and defense industries, especially in the first years of the rule of the AKP.

Eighth: Taking into account the gradual changes in the relationship, where the AKP's internal strength affected the relationship with Israel, in such a way as to downgrading some links and obligations, in a quiet and slow manner that does not lead to acute crises with Israel and does not provoke the West against Ankara.

Ninth: Not exceeding the Arab - International ceiling in dealing with the Palestinian issue, committing to a political solution based on the "two-state solution" and the Arab peace initiative, and even calling for bringing in Hamas to the peace process.

Tenth: Not exceeding the limits in the political, media, and financial support given to Palestinian factions, taking into account that the financial support has taken the form of aid and humanitarian relief projects and infrastructure support, in order not to damage the relationship with Israel prior to the crisis.

Based on these criteria, the AKP managed Turkey's relations with Israel over the years until the relationship soured over several stages.

\section{CATALYSTS AND OBSTACLE}

Turning points that affect relations between two countries:

\subsection{Relation with Palestinian authority and Hamas}

In 2006, Turkey became the first non-Arab country to officially meet with Hamas when a Hamas delegation

\footnotetext{
${ }^{13}$ Gabriel Mitchell, Israel-Turkey: Where to from Now?, (Jul 11, 2016) http://www.mei.edu/content/article/israel-turkeywhere-now
} 
led by Khaled Meshaal visited Ankara following Hamas' victory in the Palestinian parliamentary elections ${ }^{14}$. The Israeli Prime Minister, through a spokesman, stated that Turkey's reception of Hamas was "a mistake that can deeply hurt [bilateral] relations"', and so it did $^{15}$.

The situation radically changed with the growing wave of violence in Gaza, especially after the Operation Cast Lead. Turkey has openly sided not just with Palestinian, but also with Hamas. Since 2008/2009 onwards, Erdogan began to publicly blame Israel, openly accusing the UN of not applying the appropriate sanctions, calling it a terrorist state, and by appealing to the victims of the war against Gaza.

These recent events demonstrate that Turkey and the AKP appear to be doubling-down on their policy of backing the Palestinian cause in spite of the harm that this approach causes to Turkish-Israeli relations. Notably, Erdogan's formal reception of Abbas as a Head of State came after Erdogan's victory in Turkey's presidential election ${ }^{16}$. With his move to the office of president, Erdogan extended his and the AKP's "12year grip on power" in Turkey ${ }^{17}$. In his victory speech, Erdogan said that his rise to the presidency signaled the closing of doors to one era and the "first step to a new phase" 18 . If the history of Erdogan's time in power, not to mention his first actions as president, is a lesson, then this "new phase" will continue the recent trend of decline in Turkish-Israeli relations and rise in Turkish-Palestinian relations.

Ankara sees the Gaza question and the Israeli-Palestinian conflict as a "determinant factor" in bilateral relations with Israel. Therefore, Turkey makes calculations to pressure Israel and increase influence in the region by doing $\mathrm{so}^{19}$.

In the end, up to today we have reached a point of serious difference of opinion between Ankara and Israel. Therefore, even if relations are normalized after the crisis, I think they will not be friendly as much as the way they were used to be...

\subsection{World Economic Forum in Davos in 2009 and 2013}

At the January 2009 World Economic Forum in Davos, Erdoğan confronted President Shimon Peres, saying, "When it comes to killing, you know well how to kill"'20. Turkey followed these comments by excluding Israel from their previously scheduled joint military exercises.

During the debate at the World Economic Forum in Davos in 2013, Erdogan embarked on a vigorous debate with Shimon Perez, condemning the Israeli actions in Gaza. When the moderator then prevented the Turkish President (for reasons of time) from going on, the latter left the stage.

\section{The Mavi Marmara Incident}

After Hamas gained control of Gaza in 2006, Israel instituted a naval blockade of Gaza to help restrict the flow of military and militarily useful goods into the Hamas-controlled region ${ }^{21}$. On 30 May 2010, Israel attempted to avoid a confrontation with the flotilla by offering it dockage at an Israeli port so the goods being shipped could be inspected and transported to Gaza, but the flotilla refused ${ }^{22}$. The flotilla's refusal inexorably led to the Israelis' having to enforce the blockade by military means. When Israeli forces boarded the flotilla's six vessels on 31 May 2010, the only vessel whose passengers chose to fight was the Mavi Marmara, a vessel owned and controlled by $\mathrm{IHH}$ members ${ }^{23}$. nine activists were killed with several more wounded ${ }^{24}$. In

\footnotetext{
${ }^{14}$ Id.; Hamas' Meshaal: We Received Support and Advice from Turkey, HURRIYET DAILY NEWS (17 Feb. 2006), www.hurriyetdailynews.com/default.aspx?pageid=438 \&n=hamas-meshaal-we-received-support-and-advice-from-turkey2006-02-17.

${ }^{15}$ Tür, supra note 56 , at 55 .

${ }^{16}$ Joe Parkinson \& Emre Peker, Turkey Election: Erdogan Wins Landmark Victory, WALL ST. J. (11 Aug. 2014), http://www.wsj.com/articles/turks-cast-votes-inpresidential-election-with-erdogan-primed-for-win-1407658125. $17 \mathrm{ld}$.

${ }^{18}$ Id.

${ }^{19}$ SAMi KOHEN, Future of the Turkish-Israeli relations, Daily news, (1/20/2010 )http://www.hurriyetdailynews.com/futureof-the-turkish-israeli-relations. aspx?pagelD=438\&n=future-of-the-turkish-israeli-relations-2010-01-20

${ }^{20}$ Id. at 56; see also Katrin Bennhold, Leaders of Turkey and Israel Clash at Davos Panel, N.Y. TIMES (29 Jan. 2009), http://www.nytimes.com/2009/01/30/world/europe /30clash.html? _r=0.

${ }^{21}$ Joshua Mitnick, Flotilla Assault Spurs Crisis, WALL ST. J. (1 June 2010), http://www.wsj.com/articles/SB10001424052748703703704575277632709673018. $22 \mathrm{Id}$.

${ }^{23}$ Marc Champion \& Margaret Coker, Turkish Charity Group Sounds Defiant Note, WALL ST. J. (4 June 2010), http://www.wsj.com/articles/SB10001424052748704025 304575284081264400448.
} 
response to the Mavi Marmara incident, Erdoğan accused Israel of lying about the IHH's possession of weapons, calling the raid "'inhumane state terrorism'. He made his, and Turkey's, position clear when he also said, "today is a turning point in history. Nothing will be the same again'25. Further anti-Israel rhetoric was spoken by Turkish officials at an emergency U.N. Security Council meeting, a meeting that was called for by Turkey $^{26}$. At the meeting, then-Foreign Minister Davutoğlu referred to Israel's actions as "'banditry and piracy ... murder conducted by a state . . . and barbarism'”. Turkey's actions in response to the incident included expulsion of the Israeli ambassador from Turkey, recalling its own ambassador from Israel, cancelling joint military exercises, halting cooperation in the energy field, and demanding that Israel publicly apologies, compensate the victims' families, and lift the blockade of Gaza ${ }^{27}$. The scandal, without doubt, has caused serious damage to the Turkish-Israeli relations. In this case, it is impossible not to be affected in the shortrun, especially to avoid a negative impact on public opinion.

\section{POSSIBLE SCENARIOS}

From all of above discussed determinants It seems there are three possible scenarios for the relationship between the two sides.

\section{Full agreement}

\section{Collapse of negotiation}

\section{Succeeded negotiation and limited development in relations.}

The first and most likely one is an agreement that restores diplomatic ties

The second scenario: Failure of the current negotiations to reach an agreement pending changes in the regional and international climates that would benefit either one of the two sides.

The third succeeded negotiation and limited development in relations.

\subsection{Scenario Number One: Full agreement}

Two sides will succeed in their negotiations and will come to an agreement which restores their diplomatic relations to past normal one.

The current condition make this scenario more probable, Erdogan and his AKP team have realized that the 2019 elections will not be a piece of cake given the referendum results and that they need to adopt a new language to expand the 51.4 percent "yes" block. It will be quite important to what extent Erdoğan can pursue an embracing stance and language in this very difficult period.

On the international front, the AKP's convention will take place days after Erdoğan's first in-person meeting with U.S. President Donald Trump and days before he is set to meet NATO and EU leaders in Brussels. It's no secret that Erdoğan wants to repair the damage to ties with the United States and the European Union and that these meetings will provide an important opportunity to do so. We'll hear more about them from him on the convention day.

The economy is sending new alarms with figures announced regarding inflation and unemployment. The government is using each and every occasion to spread the message that things are on the right course in Turkey and that there is nothing for international investors to worry about.

If Turkey and Israel are able to restore previous relations, Israel will mainly benefit as a result of this ${ }^{28}$.

Another determinant that will push relation to full agreement Is that, After the relations between the two countries deteriorated, Ankara canceled a military treaty with Israel. As a result, the Israeli Air Force lost the Turkish airspace, used for "training" flights for many years. There is no doubt that in case of resuming the relations with Turkey, Israel will once again use the airspace of the republic. This will allow it at least partially controlling the north of Syria, Iraq and western Iran. In fact, these are the countries that are hostile towards a

\footnotetext{
${ }^{24}$ Mitnick, supra note 119.

${ }^{25}$ Marc Champion, Turkey Lashes out at Israel and Denounces 'Massacre', WALL ST. J., 2 June 2010, at A11.

${ }^{26}$ Carol Migdalovitz, Israel's Blockade of Gaza, the Mavi Marmara Incident, and Its Aftermath, CONG. RES. SERV. 5 (23 June 2010), https://www.fas.org/sgp/crs/ mideast/R41275.pdf. See also Robert Weston Ash, The Mavi Marmara Trial: Politicising the Turkish Justice System, 1 J. OXFORD CTR. FOR STUDY OF L. \& PUB. POL'Y 49 (2015).

${ }^{27}$ Migdalovitz, supra note 128, at 14.

${ }^{28}$ Rufiz Hafizoglu, Future of Turkish-Israeli relations depends on Iran, (December 2015) http://en.trend.az/world/turkey/2471459.html
} 
Jewish state in the Middle East and having no close relations with Turkey.

The second important point for Israel is that earlier, the Turkish intelligence agencies shared the intelligence data with those of Israel. Earlier, the Turkish media reported that Israel did not provide Turkey with any intelligence data. In case of resuming the relations between the countries, the National Intelligence Agency (Mossad) and the Turkish National Intelligence Organization (MIT) are expected to cooperate. As for the Israeli gas supplies to Turkey, which are presented as the main cause of restoring the relations, the countries can get the mutual benefit from these supplies in the end.

\section{Energy supply and cooperation in Syria as Determinant of agreement and cooperation}

Turkey's downing of a Russian SU-24 fighter jet along the Syrian border on November 24 has provoked crisis in its relationship with Russia, with Russian President Vladimir Putin characterizing Turkey's action as "a stab in the back." Extending beyond bilateral relations, that crisis affects Turkey's foreign policy more broadly. For Turkey, the most critical element in this feud is its energy security ${ }^{29}$.

Turkey imports most of its natural gas from Russia, and the two sides have long been engaged in talks to expand this relationship through the proposed Turkish Stream natural gas pipeline, which would channel gas to Turkey and Europe underneath the Black Sea (circumventing Ukraine). The move has prompted concerns among the Turkish leadership about the reliability of Russian gas and a corresponding search for alternative supplies in the region. In addition to discussions with Qatar and Azerbaijan, there have been more statements in recent weeks from Turkish politicians, energy companies, and others calling for talks with Israel about future natural gas imports.

The Syrian crisis is another issue on which Turkey may seek quiet Israeli support-particularly the support of Israeli intelligence, which may prove crucial to Turkish war efforts ${ }^{30}$.

The Syrian crisis provides Israel another reason to engage with Turkey. Israel is quite weary of the situation in Syria and may benefit from Turkish analysis and intelligence on this issue.

\subsection{Scenario number two: Collapse of negotiation (less probable)}

Two sides, regarding the regional and interior developments, will not succeed in their negotiations or at least could not reach a desirable agreement. The occurrence of latter scenario and delay in agreement, however, would not influence economic cooperation between Turkey and Israel. In such a case, it is also possible that Turkey, under Israelis' pressure, ask Hamas leaders to restrict their activities in Turkey.

\subsection{Scenario number three: Succeeded negotiation and limited development in relations}

This scenario took place in certain period after Marmara incident, but their mutual interests forced relation towards scenario number one for full agreement.

\section{CONCLUSION}

After more than 15 years of AKP government estrangement between Turkey and Israel, the two sides appear more than ever closer to bridging the gap between them and normalizing ties, affected by local and regional contexts and factors. The positive climate expressed by the two sides, especially Turkey, reflects the progress in the negotiations as well as the desire and need of both sides for reconciliation.

While this paper believes the more likely scenario is normalizing ties and restoring diplomatic representation between Israel and Turkey, the extent of changes especially in Turkey suggests the old strategic alliance is unlikely to be renewed, and an agreement now is more about necessity in light of emerging circumstances. Furthermore, the lack of agreement on all the details does not mean an agreement is not close, and it may mean that it needs more time to mature in light of changes on both sides of the negotiations table.

\section{RECOMMENDATIONS}

1. Most importantly, Israeli, and Turkish leaderships must create a mechanism that will allow them to effectively manage future conflicts.

2. Palestinian authority should keep relation with Turkey to protect their interest from any agreement

\footnotetext{
${ }^{29}$ Dan Arbell, Back together? Why Turkey-Israel relations may be thawing, (December 14, 2015) https://www.brookings.edu/blog/markaz/2015/12/14/back-together-why-turkey-israel-relations-may-be-thawing/ ${ }^{30} \mathrm{ld}$
} 
between Turkey and Israeli on their expense.

3. Turkey should take in to consideration its historical background and its responsibilities as a Muslim country.

\section{REFERENCE LIST}

Arbell, supra note 20, at 6; see also Kushner, supra note 20, at 23

Carol Migdalovitz, Israel's Blockade of Gaza, the Mavi Marmara Incident, and Its Aftermath, CONG. RES. SERV. 5 (23 June 2010), https://www.fas.org/sgp/crs/ mideast/R41275.pdf. See also Robert Weston Ash, The Mavi Marmara Trial: Politicising the Turkish Justice System, $1 \mathrm{~J}$. OXFORD CTR. FOR STUDY OF L. \& PUB. POL'Y 49 (2015).

Cohen \& Freilich, supra note 24, at 39.

Dan Arbell, Back together? Why Turkey-Israel relations may be thawing, (December 14, 2015) https://www.brookings.edu/blog/markaz/2015/12/14/back-together-why-turkey-israel-relations-may-bethawing/

Gabriel Mitchell, Israel-Turkey: Where to from Now? (Jul 11, 2016) http://www.mei.edu/content/article/israelturkey-where-now

Hakan Yavuz, Adalet ve Kalkinma Partisi (AKP), OXFORD ENCYCLOPEDIA ISLAMIC WORLD, http://www.oxfordislamicstudies.com/article/opr/t236/e0924?_hi=0\&_pos=8 (last visited 10 Mar. 2015).

Hamas' Meshaal: We Received Support and Advice from Turkey, HURRIYET DAILY NEWS (17 Feb. 2006), www.hurriyetdailynews.com/default.aspx?pageid=438 \&n=hamas-meshaal-we-received-support-andadvice-from-turkey-2006-02-17.

Jay Alan Sekulow, TURKEY-ISRAEL RELATIONS, Oxford Centre for the Study of Law \& Public Policy. http://policycentreatoxford.org/researchpapers/Oxford15\%20JAY\%20SEKULOW6\%20Art\%20LR\%20Format\%20TNR.pdf

Joe Parkinson \& Emre Peker, Turkey Election: Erdogan Wins Landmark Victory, WALL ST. J. (11 Aug. 2014), http://www.wsj.com/articles/turks-cast-votes-inpresidential-election-with-erdogan-primed-forwin-1407658125.

Joshua Mitnick, Flotilla Assault Spurs Crisis, WALL ST. J. (1 June 2010), http://www.wsj.com/articles/SB10001424052748703703704575277632709673018.

Katrin Bennhold, Leaders of Turkey and Israel Clash at Davos Panel, N.Y. TIMES (29 Jan. 2009), http://www.nytimes.com/2009/01/30/world/europe /30clash.html? _r=0.

Marc Champion \& Margaret Coker, Turkish Charity Group Sounds Defiant Note, WALL ST. J. (4 June 2010), http://www.wsj.com/articles/SB10001424052748704025 304575284081264400448.

Marc Champion, Turkey Lashes out at Israel and Denounces 'Massacre', WALL ST. J., 2 June 2010, at A11.

Matthew S. Cohen \& Charles D. Freilich, Breakdown and Possible Restart: Turkish-Israeli Relations Under the AKP, 8 ISR. J. FOREIGN AFF. 39, 40 (2014).

Migdalovitz, supra note 128, at 14 .

Mitnick, supra note 119.

Özlem Tür, Turkey and Israel in the 2000s-From Cooperation to Conflict, ISR.STUDIES, Fall 2012, at 45, 47.

Rufiz Hafizoglu, Future of Turkish-Israeli relations depends on Iran, (December 2015) http://en.trend.az/world/turkey/2471459.html

SAMI KOHEN, Future of the Turkish-Israeli relations, Daily news, (1/20/2010)

http://www.hurriyetdailynews.com/future-of-the-turkish-israeli-relations.aspx?pagelD=438\&n=future-ofthe-turkish-israeli-relations-2010-01-20 
Suha Bolukbasi, Behind the Turkish-Israeli Alliance: A Turkish View, Journal of Palestine Studies, Vol. 29 No. 1, Autumn, 1999; (pp. 21-35) DOI: 10.2307/2676428 http://jps.ucpress.edu/content/29/1/21

Thomas Patrick Carroll, Turkey's Justice and Development Party: A Model for Democratic Islam? MIDDLE EAST INTELLIGENCE BULLETIN, June/July 2004, http://www.meforum.org/meib/articles/0407_t1.htm.

Turkish PM Quits for Erdogan, CNN (11 Mar. 2003), http://edition.cnn.com/2003/ WORLD/europe/03/11/turkey.elections/. 